\title{
Practices of Praise and Social Constructions of Identity: The Bards of North-West India
}

Helene Basu

\section{Q OpenEdition \\ 12 Journals}

Édition électronique

URL : http://journals.openedition.org/assr/2795

DOI : 10.4000/assr.2795

ISSN : $1777-5825$

\section{Éditeur}

Éditions de l'EHESS

\section{Édition imprimée}

Date de publication : 1 avril 2005

Pagination : 81-105

ISBN : 2-7132-2044-0

ISSN : 0335-5985

\section{Référence électronique}

Helene Basu, «Practices of Praise and Social Constructions of Identity: The Bards of North-West India », Archives de sciences sociales des religions [En ligne], 130 | avril - juin 2005, mis en ligne le 02 juin 2008, consulté le 19 avril 2019. URL : http://journals.openedition.org/assr/2795; DOI : 10.4000/ assr.2795

Ce document a été généré automatiquement le 19 avril 2019.

(c) Archives de sciences sociales des religions 


\title{
Practices of Praise and Social Constructions of Identity: The Bards of North-West India*
}

\author{
Helene Basu
}

Introduction

1 In Kacch in western India, wākan karvun, to applaud, glorify, adore or eulogize the qualities of an exalted being - a deity, person, or king - is considered a vocal art which professional bards are particularly good at mastering. In this paper I shall explore cultural practices of praise in relation to social constructions of identity embedded in ethnographic realities of caste. The notion of « caste » (nyātā) as used in contemporary Kacch refers primarily to kinship relationships constituting a field for social action through which aspects of a collective social identity are constituted. Thus, in the selfunderstanding of Chāra $1 \frac{1}{2}$ the ability to master vocal forms of praise is considered a significant mark of their social identity. Here, I am specifically interested in the ways in which caste as a meaningful social reality is brought into being though practice, that is as routinised action embedded in the habitus of professional bards in Kacch ${ }^{1}$. By looking at the historical transformations of the contexts in which praise was practised by Chāra $1 / 2$ bards, a close relationship between constellations of power, religion and social constructions of identity comes to the fore.

2 In the context of Indian culture, praise is met with in both formal and informal social configurations. Praise being a variable practice, at the informal end of the scale it easily merges with flattery and boasting ${ }^{2}$. In everyday public behaviour, praise as flattery announces the superiority and achievements of political leaders, business magnates or popular celebrities such as film stars. The position of the « big man » (or « big woman ») requires subordinates to acknowledge and enhance the prestige of the ambitious leader by flattery and praise of his or her virtues. At the other end of the scale, one finds more formalised practices of praise that affirm not only the superiority of the praised object but also the accomplishments of the one who is giving voice to the praise. This is particularly true of professional practitioners of praise such as Chāra $1 / 2$ in western India 
(Rajasthan, Kacch and Saurashtra). In the former Rajput polities, the term « Chāra $1 / 2$ « referred simultaneously to people (nyātā, caste) and to a special genre of medieval poetic literature, much of which was devoted to praise. In Kacch, aptitude, proficiency and competence in composing and reciting praise poetry are itself considered praiseworthy qualities that have become part of the cultural constructions of the "nature » (svabhāv) of Chāra $1 / 2$.

3 Practices of praise do not simply build upon culturally constructed ritual, aesthetic and emotional aspects ${ }^{3}$, but also serve as important procedures in the social production of memory in which Chāra $1 / 2$ specialised professionally. In medieval regional literatures, a special genre of vira kārya or heroic poetry emerged, which was dedicated to the praise of heroic kings and warriors 4 . Medieval praise poetry composed in western India (Rajasthan and Gujarat) by Chāra $1 / 2$ poets is highly diversified according to different principles of poetic language, metres, styles of recitation and narrative, etc. ${ }^{5}$ Panegyrics praise acts of bravery by kings on the battlefield, speak in hyperbolic terms of royal victories over enemies, commend royal generosity and, above all, glorify the sacrifice of death on the battlefield. Heroic praise poetry is, moreover, expressive of the desire for fame. A king or a warrior qualifies for fame by displaying prowess and heroism which gives him a unique identity and guarantees that his name will survive his death ${ }^{6}$. Acts of praise and the promulgation of fame are further embedded in the formal framework of genealogies. The fame of a hero/king is enhanced by giving him a glorious name and linking him with the pedigree of other famous names, ultimately leading back to a divine origin. Through the promulgation of fame, individual kings and events are remembered in which an indigenous memorial tradition is established. Embedded within the learned tradition of Indian aesthetics (bhāva-rasa theory), heroic praise is tuned according to the emotion of courage (utsāha), thus evoking the corresponding heroic mood (vāra rasa). In a devotional context, praise poetry seeks to inspire diverse forms of bhakti rasa, emotions of love, in which praise in the heroic mode creates vāāra rasa, emotions of energy, vigour and courage (utsāha bhāva). From the point of view of social interaction, praise involves an emotional bond between the singers of praise and the object of their admiration in which « communities of sentiment » are brought into being.

4 In the former Rajput kingdoms in Kacch and Saurashtra, heroic praise poetry and royal genealogies memorialise the founding and conquering of medieval kingdoms, the existence of kingdoms through time, their interactions and relationships as mediated by kinship, marriage and war, and the establishment of ties of loyalty between Rajput patrons and dependent subjects ${ }^{7}$. It also depicts a social hierarchy which takes as its reference point the royal lineage and the king, making proximity to either of them a critical criterion for evaluating the rank and social status of other castes. The " community of sentiment » created by heroic praise and the promulgation of fame is at the same time a " community of memory ", constituted by the mutually interdependent qualities of feeling and remembering.

5 This article is grounded in fieldwork carried out in the second half of the 1990s in Kacch and Saurashtra. For many people in this region, Rajput kings and the kingdom of their original settlement provide an important frame of reference in constructing a local caste identity. This is also true of Chāra $1 / 2$ bards, who professionally remember local discourses of kingship in the present. Here, I shall confine myself to the Chāra $1 / 2$ caste in the former Rajput kingdom of Bhuj/Kacch. My analytic focus is directed at the relationship between practising praise in the sense of a " caste habitus » against the changing contexts and 
objects of Chāran forms of praise. In this Rajput kingdom, praise was produced as a ritual offering in two major contexts: 1) in royal court culture (darbār); 2) in the worship of the goddess. In the first context, it was directed primarily at the king, in the second at the many local manifestations of the goddess, including her human incarnations. British colonial domination of Kacch in the form of « indirect rule " transformed the basis of power to which heroic praise in the royal context was directed and thus affected productions of praise. In the postcolonial context the major object of Chāra $1 / 2$ praise is no longer the king, but an idealised image of the caste itself, epitomised in the embodiments of " human goddesses » (Chāra $1 \frac{1}{2}$ Mātājīs). By contextualising practices of praise historically, it will be shown how a new reality of caste has emerged in post-independent Kacch. Thus, in the first section of the paper I shall situate Chāra $1 \frac{1}{2}$ practitioners of praise in the historical kingdom of Kacch. Secondly, a recent human goddess, Āî Śrī Sonal Mātā, will be introduced whose cult today plays a pivotal role in the self-definition of the Chāra $1 / 2$ caste of this region. Constructions of status related to the goddess and material living conditions of Kacchi Chāra $1 / 2$ s are considered in the third section. In the last section, I shall examine a major contemporary caste ritual designed to commemorate the actions and teachings of the Chāran human goddess Āî Śrī Sonal Mātā. The birthday celebrations held in the name of this human goddess provide a major arena for the performance of Chāra $1 / 2$ ascetics, singers and poets. Examples of their poetic productions are found in Appendix 1 and 2. Through strategies of ritualisation, I argue, new commemorative caste rituals have been created that depend on practices of praise. In this way, the lived reality of the contemporary Chāra $1 / 2$ caste is produced, manifesting one facet of the diverse social and local realities of caste in postcolonial India.

Practitioners of praise in the historical kingdom of Kacch

6 The gādi (throne) of Bhuj goes back to the sixteenth century. It was the throne of Jādejā kings who later became identified with the whole peninsular of Kacch in the most western part of Gujarat, forming a link between the Saurashtra peninsula and Sindh (in Pakistan). Kacch was one of several Rajput polities that consolidated themselves in the 1500s from Rajasthan to Saurashtra, forming a hierarchy of rule. These Rajput kingdoms were situated at the periphery and under the sovereignty of Delhi or of regional sultanates and Mughal dominions (Ahmadabad). In the light of the emergence of different traditions of rule on the Indian subcontinent, polities in Western India were dominated by Rajput styles of kingship implying closely interwoven webs of kinship in combination with patron-client-relationships ${ }^{8}$. Interactions between Rajput kings were governed by attempts to enlarge their respective spheres of rule through conquest, war and strategically placed marriage alliances. The sphere of rule of the Jādejā kings of Bhuj was more or less confined to the peninsula. Like other Rajput kingdoms in neighbouring Saurashtra, the prosperity of the gādi (throne) of Bhuj depended largely on trade and merchant activities'. In the eighteenth century, five flourishing ports contributed considerably to the power of the throne of Bhuj. The towns of Kacch were important commercial centres connecting long-distance inland trade-routes with transatlantic sea routes. The most prosperous merchant communities were Hindu-Lohana, Jain-Vania and Muslim-Memon, who controlled different trading activities. Rajput court culture and trade worked together in favouring the development of artisan crafts. Steel products (swords, daggers, knives), textile and woollen handicrafts and leatherwork were manufactured for export as well as for the Rajput aristocracy. In addition to artisans, a large part of the population of Kacch were pastoralists and herdsmen, such as Ahir 
raising cows, Chāra $1 \frac{1}{2}$ raising water buffaloes and horses, Rabāri breeding camels, and Bharvād keeping sheep and goats. Agricultural production was pursued by members of artisan and pastoralist castes, whereas peasant castes such as the Leva Kanbi (Patidar) from mainland Gujarat settled in significant numbers in Kacch only in the nineteenth century.

$7 \quad$ The overall relationship between the king $(r a j \bar{a})$ and his subjects (praja $)$ was determined by the exchange of gifts and services. Seen as the supreme givers of gifts, Jādejā kings compelled their subjects to loyalty through the bestowal of royal land grants and the granting of privileges, whereas the subjects in turn were obliged to pay tribute, revenue, and taxes and to provide military and other services. The relationships between the king and the people were concretised and personalised in the context of the royal court ( darbār), which was composed of individual members of the various social groupings constituting the royal subjects. For example, the ministerial post of the divann, second in power only to the king, was held in Bhuj for generations by a member of one of the merchant castes, most often a Lohanā (sometimes Jain or Memon). The dī̄ān was responsible for the administration of the kingdom, especially for the collection of taxes, his main obligation being that he apply his caste-inherited skills (his « merchant habitus ») to generating greater monetary wealth for the king. While the divān derived his importance from the immediate economic and political aspects of royal power, the ritual and ceremonial dimensions of royal power were made manifest by the work of praise of the bards (poets) and genealogists. For generations, members of the Chāran caste held a post called rājkavi, royal poet/bard, at the Bhuj darbār. The rājkavi offered dānastuti, heroic praise representing a symbolic tribute offered to the king. The value that was attached to Chāra $1 / 2$ bards in the royal context may be also inferred from a grant made by a Jādejā king in the eighteenth century, which allowed Chāra $1 \frac{1}{2}$ literati to establish a formal school dedicated to the teaching of literature ${ }^{10}$.

8 According to Kacchi conceptions of kingship, the lineage of the Jādejā kings was empowered to rule by a goddess called Āśāpūrā. By her grace, Jādejā Rajput warriors were made kings and provided with the śakti (power) of the goddess. The consecration of the king thus depended upon notions of sacred power, as conceived in the term śakti. At the royal court, Chāra $1 / 2$ bards were part of a circle of ritual experts each of whom contributed to the annual consecration of the king during the royal celebrations of Navrātrī, the feast of the "Nine Nights of the Goddess ». A sacrificial symbolic order was thus created locally in which the ritually and politically powerful king required assistance from specialists such as bards and ascetics. This sacrificial order was anchored in the pattern of worshipping the single goddess.

Brahman priests played a secondary, almost non-existent role in the ritual scheme of Jādejā kingship in Kacch. They were, of course, present at the royal court. The services of Brahman priests (Räjgor) were particularly important for the performance of royal lifecycle rituals; moreover, queens often maintained intimate relationships with their Brahman astrologers, who served as personal confidantes. But in the most important rituals of kingship, especially those of Navrātrī, in which the symbolic power of the king was regenerated and reproduced by performing buffalo sacrifices for the goddess, Brahmans had no important role to play. Instead, priestly functions were assumed by ascetics of the Kāpdīa and Kānphata orders (who both worship 堅śakti as the supreme being and Śiva in his androgynous form). In the sacrificial rituals performed by the king at the royal state temple of Ásāāūrā during Navrātrī, Kāpdīa and Kānphata ascetics 
served as priests of the goddess. Moreover, the buffalo sacrifice performed by the king, and by Rajputs in general, required a special ritual service from Chāra $1 / 2$ - in this case not from male bards, but from women. The first blood flowing from the neck of a sacrificed buffalo had to be received by a Chāra $1 / 2$ woman. After consuming the sacrificial blood she hosted the goddess in trance, whom she in this way incarnated or embodied for the duration of the royal sacrifice.

This practice of a Chāra $1 / 2 \overline{1}$ drinking the blood of the sacrificial victim, being possessed by her and therefore turning into an incarnation of the goddess - anchors a vital regional belief in rituals of kingship, namely, that the goddess be born in a Chāra $1 \frac{1}{2}$ woman and thus transforms her into a « human » or « living " goddess. This is the second pre-colonial context in which Chāra $1 / 2$ bards produced poems and songs of praise, in this case stutis praising the goddess. Stutis are addressed to the many Chāra $1 / 2$ Mātājīs, or " human goddesses » of the past, who helped the Jādejā kings gain power, destroy their enemies or save their soldiers from hunger and thirst by miraculously producing food and water ${ }^{11}$. Not only in Kacch, but all over Saurashtra and Gujarat too, temples for goddesses are found who are believed to have been a historical woman, a Chāranī, who was transformed into a powerful Devī (one famous temple is that of Bahuchārya Mātājī in northern Saurashtra). Such women are deified as Chāra $1 / 2$ Mātājīs. They are seen as having guaranteed the moral rule of kings, commanding a double-edged power (śakti): the power to punish an immoral king by cursing him, and the power to reward him with âsisivād and acknowledge his justness, generosity and rule in accordance with dharmic principles. Chāra $1 / 2$ Mātājīs, moreover, guaranteed the moral status not only of the king but also of the men of their own caste, of the bards and poets whose words represent truth. Consecrated Chāra $1 / 2$ femininity was required by the king as much as by their men. Thus, one finds a close connection between the consecration of a Rajput king and the consecration of the status of Chāra $1 / 2$ bards. Ultimately, all qualities of Chāra $1 / 2$ expertise, but especially their power of speech, are explained by the special relationship that binds Chāra $1 / 2$ identity to various manifestations of the goddess, particularly to Sarasvatī and Pārvatī. I shall return to this point.

11 Colonialism changed the overall dynamics that infused the social reality of the precolonial kingdom of Kacch. As a local power who might prove of use in their own schemes, Kacch came into British cognisance comparatively late, at first mainly for strategic reasons in terms of providing a closer route to Sindh. At the beginning of the nineteenth century, the numerous little kingdoms of Saurashtra were turned into " pacified " territories by Colonel Walkers " settlement policy. Only afterwards did the British become aware of Kacch as a « lawless », « disorderly » region from where " pirates » by sea and « dacoits » by land threatened the newly established order of indirect rule in Saurashtra. The king of Bhuj was accused of harbouring and protecting " criminals » in his kingdom and thus violating "British interests ». As long as the kings of Kacch did not accept British terms of rule, the kingdom was perceived as a disturbing and threatening presence that had to be subjugated. After years of tedious struggle with resisting kings and divāns in Bhuj, the British finally succeeded in placing a British Resident at the court in Bhuj in 1812. A royal successor was found, who was only fourteen years old and thus could still be moulded by British-monitored education. From the first half of the nineteenth century onwards, every Jādejā king was educated under special British guidance, in order to make him an appropriate « native ruler » by colonial standards. The Jādejā kings of Bhuj ultimately became most loyal allies of the British. 
12 After the British succeeded in acquiring influence and ultimately control over the throne of Bhuj, the organisational structure of the kingdom was frozen into a fixed, «traditional » form of royal rule. Colonial subjugation made Bhuj the capital of the Princely State of Kacch operating under British sovereignty, and thus turned the gādi (throne) into one of the numerous " hollow crowns " and " theatre states " which emerged in response to colonial domination all over India ${ }^{12}$. The king was now the administrator of his kingdom, no longer the ruler of a state. The more his real power declined, the greater became the pomp and the ceremonial displays that surrounded the king. While on the one hand the Rajput aristocracy was socialised into British colonial modernity, on the other hand the king continued to represent ritual power in his kingdom. Royal sacrifices and the performances of Chāra $1 / 2$ praise singers remained vital in the ceremonial realms of court life throughout the period of colonial domination. But they now performed «theatre praise ", replacing, for example, heroic battle with the favourite colonial pastime of hunting. The Rajput king was now praised for the bravery and intelligence of the hunter, instead of the heroism of the warrior. Ritually, the kingdom continued to exist, and Chāra $1 / 2$ were amongst its most ardent defenders, praising its past fame and glory.

13 Colonial modernity affected people in Kacch to different degrees. Brahmans, Hindu and Jain merchants and the Rajput aristocracy were vitally involved in negotiating, contesting, utilising and capitalizing on colonialism, thus transforming their practices and forms of habitus to different degrees. In the case of the Chāran the confrontation with colonialism resulted in the disentanglement or fragmentation of formerly closely related and context dependent practices. Thus, the Chāran »s aptitude for poetry and singing was associated with a claim to truth which in turn provided a rationale for two more important roles fulfilled by men and women: to guarantee the moral order by acts of self-inflicted violence (trāgu) and the embodiment of the goddess through women. As in the Rajasthani kingdom of Sirohi studied by Vidal, in Kacch and Saurashtra too the practice of trāgu was criminalized by the colonial government ${ }^{13}$. While remembering the past, praising kings and female embodiments of the goddess in royal sacrifices became part of the Chāra $1 / 2$ »s role in the "theatre kingdom », in their poetic productions Chāra $1 / 2$ lamented the decline of " culture ${ }^{14}$. It is interesting to note that there is an apparent gap in the memorization of deified Chāra $1 / 2 \overline{1}$ s of medieval and modern times ${ }^{15}$. No famous Mātāji (human goddess) born in the nineteenth century is remembered in the Chāra $1 / 2$ caste in Kacch. It is only in the 1920s that a powerful living goddess was born again. This was Āî̀ Śrī Sonal Mātā who was not so much connected to life under colonial conditions, but more so to the abolition of the kingdom and the necessity of reforming Chāra $1 / 2$ customs after independence.

Thus, while Kacchi traders settled in Bombay and elsewhere in India became active supporters of Mahatma Gandhi and the Indian nationalist movement, the latter did not gain great popularity in Kacch itself. Members of the Chāran caste remember as most severe the changes they experienced as a consequence of the abolition of princely states and royal rule. It was in these times that the human goddess Āī Śrī Sonal Mātā entered the world in order to guide her people along the route to modernity.

Transformations of praise after independence

In postcolonial Kacch, heroic praise of kings was transformed into devotional praise lauding the prestige of the caste and Chāra $1 / 2$ human goddesses. After the reality and social relevance of their former ritual role was lost to them, Chāra $1 / 2$ responded to the political changes affecting their local life-worlds through the medium of a new type of 
human goddess, Chāra $1 \frac{1}{2}$ Mātājis who advocated asceticism and the social reform of customs and life-style. ${ }^{1} 6$ In this social context, the place and importance accorded to nationalist leaders and reformative thinkers in the Indian middle classes is taken by $\bar{A} \overline{\mathbf{i}}$ Śrī Sonal Mātājī who is transformed by praise and fame into an icon of Chāra $1 / 2$ caste modernity.

Āì Śrī Sonal Mātājīi is the " human goddess " who is most immediately associated with independence and social change. She enjoys great popularity and her actions are seen as exemplary by many contemporary Chāra $1 / 2$ women, who are now following an ascetic lifestyle and are also venerated as " human goddesses ». While in the past Chāra $1 / 2$ Mātàjīs have always been marked as unmarried, the importance of the act of world renunciation has received an increased emphasis in contemporary discourse. Ordinary women, who are married, raise children, work in the fields and dutifully participate in the cycles of gift exchange constitutive of the universe of kin relationships (vevarik sambandh), are never raised to being an object of praise. Although in principle śakti resides in every woman, only those who have actively enhanced their power by leading a life of asceticism may qualify for the performance of public praise by Chāra $1 / 2$ men. Chāra $1 / 2$ Mātājīs are praised for their renunciation of sexuality (ideally a Mātāji never marries), their restricted diet (only milk products, no grains), individual penances (keeping vows of silence, undertaking pilgrimages) and exercises of meditation. ${ }^{17} \mathrm{~A}$ woman $» s$ reputation and fame grows in accordance with the perceived degree of power (śakti) she has achieved by performing ascetic acts. Conversely too, the more praise a Mātajī receives, the greater is her śakti thought to be. The turn to asceticism as the major quality of a Chāra $1 \frac{1}{2}$ Mātājiis also communicated by the saffron colour of her dress, the colour of the Hindu ascetic. While old Chāran Mātājiis are never represented in the saffron colour of the male Hindu ascetic, contemporary « human goddesses » are always recognisable by their dress having this colour. ${ }^{18}$

Āî Śrī Sonal Mātājīi, the most venerated and praised Chāran Mātājī of recent memory, was born in the 1920s into a Chāran subcaste in Saurashtra whose members derived their livelihood from pastoralism. Rejecting marriage, Āì Śrī Sonal Mātājī professed a new kind of asceticism which stressed, in addition to penances, meditation and worship, personal manual work. Growing up in close vicinity to Porbandar, Gandhi »s home town, her hagiographers claim that she met Gandhi in person and to have been influenced by his ideas, especially his ethics of labour. The human goddess is not only credited with having induced her own immediate caste to change to settled agriculture instead of raising cattle, but also with a host of other suggestions for reforming Chāran habits. Most of Āi Śrī Sonal Mātājī »s messages and demands for reform echo familiar issues of the 1950s and 1960s in post-independent India described under the heading of «Sanskritisation ». She preached vegetarianism and anti-alcoholism, rejected blood sacrifices, rebuffed the ideas and practices of possession by the goddess, and, most importantly, urged her caste to educate their children. Until her death in 1975 , she regularly toured « her territory ", that is, Chāran settlements all over Saurashtra, Kacch and parts of south Rajasthan. In Kacch, her passionate lectures were particularly well received, leaving a distinct mark in the contemporary social life of the caste, as will be shown in the last section, that deals with a commemorative ritual performed for this human goddess.

18 The changing political circumstances affected cultural constructions of Chāran Mātājis and the objects of praise, but less so the dispositions of the Chāran, that is, the wish and ambition of individuals to develop expertise in performing praise poetry. Poets continue 
to compose praise poetry, and singers continue to celebrate a praised object. But nowadays praise is only rarely directed at Rajputs or heroic warriors, except when old poetry is recited, or in the context of genealogical performances at marriages, when lineage ancestors are remembered. Objects of contemporary acts of Chāran praise are more often gods and goddesses, individuals (patrons) of any superior standing (a merchant, a sādhu, a politician), or sādhus and female ascetics venerated as human goddess. Most importantly, however, the Chāran caste (nyātî) has itself become a favourite object of praise.

Chāran practices of praise are now performed mainly in the context of caste. This also leads to the peculiar situation that although female and male ascetics have "left the world » in mind and life-style, they still live in close proximity to that same world of their birth and caste. Sādhus (ascetics) and Mātājīs, along with poets and singers, constitute the " sacred face » of the Chāran nyātī, who worships her own consecrated and deified image in the form of the " human goddess». It is thus no longer the king who symbolises entry to the larger social world by providing the position to become a praiser; rather, ascetic females and males have taken over this role. As a corollary, ascetics open the way to contemporary social and political networks that extend beyond the boundaries of close kinship circles of caste.

The praisers ' caste

About 35,000 people identify themselves as belonging to the Chāran caste in Kacch, which now represents the largest district in the state of Gujarat. Here, most Chāran are called by the name "Gadhvi ». Gadhvi people are convinced that all those who belong by birth to the Chāran caste (nyātì) are " of the same kind ». Being of the same kind implies certain dispositions, such as the ability to compose poetry, recite it in many different styles, the capacity to remember historical knowledge, a love of the play of words, and above all, strong inclinations in both men and women towards asceticism. While not every single caste member may turn out to be a gifted singer, a poet or a Mātājī, it is generally believed that from no other caste were so many proficient artists and charismatic religious personalities born. Singing and reciting poetry is a favourite activity pursued regularly not only by artists, ascetic women and male ascetics, but also by many ordinary people. In some villages, poetry and singing competitions are held almost daily. Large groups of young men aspire to become a recognised Chāran artist, a karlekār, either as a singer, musician or orator. A specific caste habitus is thus socialised and internalised by everyday practices of singing, reciting and remembering.

21 In the context of the urban middle-classes in Kacch, among people mostly of Brahman, Patidar, Lohanā and other merchant-caste backgrounds, the Gadhvi presence is peripheral. From a middle-class perspective, Gadhvis are stereotypically seen as « rustic rurals ", easily identifiable by their uniform dress: men in white with a coloured shawl, women in black skirts, colourful blouses and a red headscarf. Their art, however, is appreciated even by the middle classes. Since the 1970s, the local radio station $(\bar{A} k \bar{a} s \bar{s} v \bar{a} / 2 \bar{\imath})$ has run a popular programme called "lok git" (folk music), in which performances by individual Chāra $1 / 2$ musicians and vocal artists are regularly broadcasted (along with those of other Kacchi musicians).

The majority of Gadhvi people have settled in villages in the southern half of the Kacchi peninsula, where well irrigation built in the 1950s facilitates the agricultural production of cash crops. Economically, Gadhvi peasants have profited from land reforms and the green revolution that occurred all over Gujarat. They grow cotton, groundnuts and, most 
importantly, maintain orchards in which dates, chikku, bananas and other fruits are produced. While the richest section of the Gadhvi caste is represented by landowners controlling thirty acres or more, the poorest are landless. Landless Gadhvi tend to seek employment from wealthier landowners of their own caste. On the whole, Gadhvis have acquired modest economic affluence, which, however, cannot compare with the wealth of rich capitalist farmers from the Leva Kanbi that is, the Patidar caste in other villages. Much of their wealth comes from remittances sent by migrants. Whereas few Chāra $1 / 2$ have migrated from Kacch, a large percentage of Patidar live abroad, in East Africa, Great Britain or the USA. Patidar peasants in Kacch were able to use these remittances to invest more economic capital in artificial irrigation projects, highbred seeds and the latest agricultural technology than any other peasants.

According to Gadhvi conceptions, the Chāra $1 / 2$ have received their special dispositions from the goddess, the Devī. They perceive themselves as instruments of a specific power,

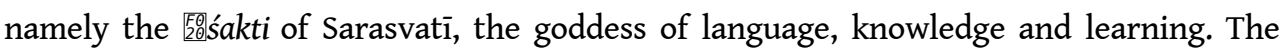
first definition of a Chāra $1 / 2$ is: he/she is a devīputra, or a devīputrī, a " son /daughter of the goddess ». The origin of the Chāra $1 / 2$ caste is connected to the goddess Pārvatī. By defining their status as deviputra, the caste charter situates the Chāra $1 / 2$ consciously outside the Brahmanic, varna- based definition of social status. Rather, the distinct status of a deviputra is defined by female sacrality, by the human goddesses, the past and present Chāra $1 / 2$ Mātājiss, who populate the symbolic landscape in Saurashtra and Kacch. What for analytic purposes can be translated as habitus is, according to Chāra $1 / 2$ notions, engendered in their svabhāv, the nature given by the goddess as a gift.

These talents or « caste powers " (śakti), the gift of the goddess and the specificity of a Chāra $1 / 2$ habitus are engrained in the body, being anchored in speech patterns, rhythm mnemonics and writing. Embodied knowledge and skills are transmitted in closely knit networks of kinship and caste. Moreover, this habitus makes sense only in a social field in which singing, reciting poetry and narrating histories are valued actions. While the caste has become a significant audience, artists also contribute in a wider social field to the production of local public culture. Performing for the local radio station, writing for the local newspaper or singing before a multi-caste audience at religious festivals provide ways for Gadhvi to act according to their dispositions.

In this way, a specific cultural capital of the Chāra $1 / 2$ caste is produced. The local Gadhvi elite consists of those who control the cultural capital of the Chāra $1 / 2$, that is, those who command competence in the fields of historical knowledge and the mnemonic techniques of praise accumulated over time. The top urbanised elite of the caste in Kacch is formed of a small number of college teachers, lawyers, government employees, politicians, and rich landowners. In addition to their respective jobs, many of them spend time cultivating one or several of the traditional arts and forms of knowledge cultivated in their caste. Moreover, Chāra $1 / 2$ poets and literati often command several languages, such as Kacchi, Gujarati, Hindi and even Sanskrit. The language most esteemed by Chāra $1 / 2$ poets however, is Brj bhāsā. A college teacher of Sanskrit may composes verses in Sanskrit, but in a metre which accords with the rules of Chāra $1 / 2$ literature; a lawyer might be a gifted singer, etc. Whatever their formal profession may be, the greatest respect is accorded to a writer of a caste history, a writer of a hagiography of a Mātàjī, a famous ascetic, poet or renowned singer, or a highly esteemed female ascetic (human goddess). Individual achievement in terms of mastering a Chāra $1 / 2$ art increases the prestige and influence of a person within and beyond the caste. Referred to by common 
people as " our big people " (vadil loko), the elite rules over the rest of the caste. Big people write in newspapers, journals and books about the history of the Chāra $1 / 2$, they publicly recite praise, sing bhajans and other devotional music, or else teach religion, especially if they assume the role of an ascetic or a " goddess in a human body ». Thus, those who control the cultural capital are those whose names are famous, at least in Kacch, those whose voices are heard, whose opinions on political issues matter. Caste leaders invest the cultural capital of their Chāra $1 / 2$ identity in the competition with other castes over political influence and power.

The formal organisation of the caste on the district level, the "Kacch Chāra ${ }^{1} / 2$ Samāj », is controlled by these leaders. Positions of caste leadership are dominated by men, big landowners, lawyers and teachers. The head organisation of the "Chāra $1 / 2$ Samāj " represents the political interests of the caste in relation to the state, especially in mediating demands in regard to affirmative action (Chāra $1 / 2$ now are classified as $\mathrm{OBC}$, [Other Backward Caste »s]). The organisation also administers funds collected regularly from every Gadhvi household for the maintenance of social institutions benefiting the caste. Educational scholarships are given to students from poorer families from caste funds. In the 1970s, a hostel was built in the town of Mandvi for Gadhvi village boys enabling them to go on to higher education. More recently, a hostel for girls has been added. In addition, the caste council also intervenes in the customary life-style of its members. The Chāra $1 / 2$ Samāj regulates the dress code to be followed by Gadhvi women for example, allowing girls to wear a salwār kamāz when going to school, but demanding they wear " Chāra $1 / 2$-style dress " when attending formal gatherings of the caste. The " Chāra $1 / 2$ Samāj » also implements the reform of specific practices, such as the abolition of bride-wealth payments before marriage. Divorce and violations of norms of endogamy are also brought before the caste council. In extreme cases violators of norms are officially expelled from the caste. This happened only ten years ago to a Gadhvi woman who went for higher studies and married a Brahman man. On the whole, the caste council controls the behaviour of caste members and demands conformity to caste norms ${ }^{19}$. A vital occasion for demonstrating the validity and moral superiority of these norms is provided by the celebrations commemorating the human goddess Āî Śrī Sonal Mātājì.

The ritualisation of praise: celebrating caste

The annual birthday celebrations in honour of Āī Śrī Sonal Mātājī are a major occasion at which contemporary Chāra $1 / 2$ adepts practice the art of praise. Institutionalised by the caste council (the Kacch Chāra $1 / 2$ Samāj) from the beginning of the 1980s, commemorative celebrations held in the name of Āi Śrī Sonal Mātājī are referred to as "Sonal Bīj » (bijj = first sickle of the moon, birthday). The «Sonal Bij » festival provides staged performances and speeches given by caste historians, vocal reciters, bhajan singers, ascetics, Mātājīs and caste leaders. Except for a few selected guests (for example, prominent devotees of a Chāra $1 / 2$ ascetic or a local politician), the audience consists almost entirely of Gadhvi from the district of Kacch. By listening to the speeches of their vadil loko, or "big people ", ordinary Gadhvi are taught about the historical greatness and the fame of the caste to which they belong. The rhetoric of praise permeates the speeches, poetry recitals and songs, and elevates the Chāra $1 / 2$ caste. A Mātāji is praised by evoking her birth as a Chāra $1 / 2 \overline{1}$ and vice versa, and the greatness of the caste is applauded by commemorating the many famous sacred women, the human goddesses, of the Chāra $1 / 2$. The celebrations of the birthday of Sonal Mātājì present themselves as the outcome of ritual strategies or ritualisation through which the modern Chāra $1 / 2$ caste defines itself. 
The ritual performances celebrating the modern Chāra $1 / 2$ caste are held in the building of the "Chāra $1 / 2$ Boarding ", the boy »s hostel in Mandvi. This building also serves as the administrative head office of the district organisation of the caste (the Kacchi Chāra $1 / 2$ Samāj). It houses a small temple dedicated to Āī Śrī Sonal Mātājīi, where her photographs, a triśūl and a small icon of Jagdambā Devī are kept. Visitors to the Chāra $1 / 2$ Boarding are first brought to this temple and told the story of how Āî Śrī Sonal Mātàjī had come to preach in Kacch in the 1950s and 1960s and then prompted the local Gadhvi to provide their sons with education. She herself, so the story goes, had collected the funds to enable the building of the boy »s hostel.

In the course of my fieldwork, I could witness « Sonal bij » twice, in 1996 and in 1998. Each time, the two-day celebrations of "Sonal bij » were organised by the caste leadership. An organising committee was entrusted with the organisation of the actual event. The tasks of the committee included sending invitations to prominent performers, organising a work force of Gadhvi boys and men to cook and serve at the feast, selecting people to bestow flowers and ceremonial gifts upon the most prestigious performers at the beginning and end of the celebrations, and finally drawing up the actual schedule.

During "Sonal bij », praise remains the most important ritual act, performed in different fashions, modes and genres. In these ritualised performances, we meet with four dimensions of praise: praise in the form of a ritual offering, praise in the form of spreading fame, praise in the aesthetic formal framework, and praise as an emotion by which a community of memory and sentiment is forged. The beginning of the ceremonial programme is marked by praise being offered ritually to the goddess Āi Śrī Sonal Mātājì. These are called Mātajji na stuti (devotional praise of the goddess). Praise poetry of the Mătājī na stuti type are composed by individual poets and recited publicly by devoted men and women of the Gadhvi caste. They contain verses like the following:

You have vowed to give your beautiful body, day after day

Taking is not (in your nature), you wonderful, wonderful Sonal Mātājī

After the inauguration of the programme with ritual offerings of Mātāji na stuti, learned men give lectures and speeches on the history (itihās) of the Chāra $1 / 2$ caste. In contrast to praise performed in the context of the darbār, the royal court, which celebrated the king and the hero, the elevated object of praise is here the caste itself. The origin of the Chāra $1 / 2$ on the peaks of the Himalayas, high up in the realm of the devlok, is used as a metaphor for the high status that Chāra $1 / 2$ may also claim in the lower world on earth and in the present. The lectures then go on to detail the wanderings of the ancestors, how they came to earth, which routes they took, how they began to breed water buffaloes, how they attached themselves to Rajput heroes, how Chāra $1 / 2$ warriors and Mātājīs helped Rajput kings to found their kingdoms and finally, how local Gadhvi villages were established in Kacch. A recurrent theme in historical narratives is the close relationship that bound Chāra $1 / 2$ to Rajput patrons. Praise of Rajput heroism not only elevates the status of the patron but also enhances the respect enjoyed by the producers of fame. Narrators dwell at length on the privileges that Chāra $1 / 2$ ancestors had enjoyed in recognition of their services, such as revenue-free villages, huge amounts of royal gifts (dān), close access to the court and other favours. What narrators praise most, however, is the readiness of a Chāra $1 / 2$ to sacrifice his or her life in order to remain truthful, as well as for the moral benefit of the patron (trāgu). Towards the end of their aggrandised accounts of the history of the caste, speechmakers draw lessons for the present: loyalty to leaders, readiness to 
sacrifice one "s life for a moral cause, and honouring the customs of the caste (rit rivāj), which was created by the ancestors for the good of their descendents. These remain the moral duties of any living Chāra $1 / 2$ today.

While historical lectures are given during the day, the evening is reserved for the performance of poetry and devotional music by renowned artists (karlekār). Invited like the learned lecturers, the top layer of performing Gadhvi artists are those whose names and reputations extend far across the boundaries of the Chāra $1 / 2$ caste. The utmost respect is given to ascetic artists. Although asceticism posits that the renouncer severs all ties with his former life, especially with his family, relatives and caste, male and female ascetics of the Gadhvi still remain bound to their caste, even if in a transformed way. Male and female ascetics remain unmarried and live beyond their families, but their first audience, those who acknowledge their claim to a superior, consecrated status, are from their own immediate caste. Only when they spread his or her fame are members of other castes likely to be attracted too. One of the most prestigious Chāra $1 / 2$ ascetics is Nārāyan Svāmī, a follower of the path set by the Nāgā branch of the Dasnāmī order, who commands a large following of devotees, including migrants in Britain ${ }^{20}$. All his devotees venerate him not only for being a fierce and spiritually powerful ascetic, but also for the power, the ${ }_{[0}^{\mathbb{E}}$ śakti, of his music. Nārāyan Svāmī excelled as a famous singer of bhajans, which he performed with a group of musicians, and his devotees were ardent consumers of his tapes. Tapes of bhajans sung by Nārāyan Svāmī were and are produced in a studio owned by the ascetic. Situated in the city of Rajkot in Saurashtra, the studio produces and sells audio-tapes of both live performances and studio recordings. Nārāyan Svāmī performed at all the major religious festivals in Gujarat, his performance at the « Sonal Bỉj » celebrations being considered a great attraction.

While the genre of bhajan is a popular form of devotional music practised widely in Kacch and India, both on stage and spontaneously, there are other genres of artistic vocal performances that the Chāra $1 / 2$ claim as " their own ". These are literary, poetic and recital styles, commonly summarised as Chāra $1 / 2$ sāhitya, or Chāra $1 / 2$ literature. The formal aesthetic frame in which the different forms of praise are embedded are defined by considerations of metre and other rules for composing poetry. The aim of contemporary Gadhvi artists is not to dislocate « old » forms and create new ones so much as to devise a strategy to make oneself a name, by achieving perfection and mastery over a particular style or genre. This does not mean that no variation is possible in poetic forms; on the contrary, mastery over style is displayed in able improvisations, that is, by individualising the application of formal rules.

At the celebrations of the birthday of the goddess, composers and reciters of poetry display old and new creations, drawing on the whole register of Chāra $1 / 2$ styles of recital. The majority of performers are men, although a few gifted women singers also display their skills. In addition to duho (two-line songs) and bhajan singing ${ }^{21}$, a favourite genre of poetry recital is called $c \bar{a}^{1} / 2 d$. It is also associated with the Goddess, and is the traditional metre form for composing praise poetry in her name. $C \bar{a}^{1} / 2 d$ expresses the different contexts, moods and themes of a poem through a special style of rhythmic recitation. It may sound like aggressive shouting, being recited on the pitch of the voice, being a type of poetry which was sung on the battlefield in order to instil bravery and a mood to fight in soldiers, or like drops of water or the voice of a bird, creating a vocal image of a garden in which the goddess is residing. Many $c \bar{a}^{1} / 2 d$ are recited in praise of Sonal Mātāji. In the poem $C \bar{a}^{1} / 2 d$ Bhujangi, for example, every line starts with "namah" (adoration to): then 
specifying her qualities (a light in the darkness), ending the verse by: "« namah Sonal Âî mahā » (« the greatest »). The life-history of Sonal Mātāji is poetically recorded in a total of eight long verses, which are recited for about an hour. Often, moreover, not only different genres of speech recitation, bhajan, duho and $c \bar{a}^{1} / 2 d$ but also languages (Kacchi, $\mathrm{Brj}$, Gujarati, Sanskrit) are mixed in one performance ${ }^{22}$.

As the night of « Sonal Bỉj » proceeds, more and more of the younger and less reputed Gadhvi artists display their knowledge and mastery of the vocal arts. The staged performances heighten competition between younger Gadhvi artists. Fame, a well-known name, public reputation - many young Gadhvi men aspire to these goals. A road to fame may also be found by addressing new ideological issues in the code of Chāra $1 / 2$ praise. Thus, even praise songs for the Hindu nationalist goddess Bhārat Mātājī may be heard occasionally. In recent years, some politically ambitious young men have begun to deploy their talents for the benefit of the type of Hinduism which is being propagated by the Vishwa Hindu Parishad and the RSS ${ }^{23}$.

The second and final day of the celebrations is reserved for speeches (bhäsan) given by the most prestigious local Mātāīis (ascetic women) and by caste leaders. These concern the present state of the caste. Mātajjis in particular make themselves heard by the opposite of praise: they complain and grumble and point out all the moral flaws in the everyday behaviour of Gadhvi that call for severe rebuke. Playing cards, drinking alcohol, men beating their wives, women gossiping instead of doing work and similar issues of the everyday are passionately castigated in the speeches made by ascetic women, who urge their caste members instead to lead a hard working life, to look after the education of their children, to serve (sevā) the goddess, to act piously, and to seek the wisdom and advice of ascetics. Like knowledgeable men and vocal artists, women ascetics also compete for recognition and veneration as human goddesses. Since Sonal Mātāji embodies an ideal, preaching social reform like her is a common strategy employed by ascetic women, even though currently few of the " human goddesses " seem to be as charismatically inspired. Moreover, most of the critical issues that Sonal Mātājī addressed - especially blood sacrifice and possession - have lost much of their vigour because they are hardly practised any more. Yet, having morally reprimanded their unreasonable and stubborn fellow humans, Mātājīs conclude the event by bestowing blessings (áśrvād) on the audience.

On the whole, acts of praise performed in commemoration of Āî Śrī Sonal Mātājī evoke feelings of belonging and shared emotions of love and adoration for the goddess through caste practices. Caste may then be experienced as a " community of sentiment ". Sentiments extend to a heroic past which is brought into the present by Chāran Mātājīs. All the displays of caste knowledge and performative skills are ultimately seen as a form of sevā or worship, that is, of religious service being rendered out of devotional love ( bhakti). The sharing of sounds and meaningful words uttered in sevā can be understood as embodied love, prem, as the Chāra $1 / 2$ say. Sevā, worship or ritual service, is rendered out of feelings of devotional love. Thus, through strategically placed acts of praise and remembering, the idealisation of the caste-self may be experienced creatively in a " community of sentiment and memory ". The sentimental bonds and emotions that are evoked by singing, listening to historical stories and to poetry contribute to a heightened awareness of the svabhāv of the Chāra $1 / 2$ caste, and their « nature » - or habitus.

Conclusion: on the diversity of the social realities of caste in modern India 
40 I hope to have shown that looking at caste through the prism of praise reveals how caste is created as a lived reality in the present by people who act strategically in order to reach culturally defined goals. I have attempted to build a genealogy of praise as a caste practice. In the precolonial Rajput kingdom of Kacch, praise was a ritualised practice performed in the context of the darbār (royal court). Through praise, the king was elevated to a superior, heroic and ultimately consecrated position. Chāra $1 / 2$ bards, of course, were not the only praisers in the region, many other castes also practise praise singing. ${ }^{24}$ But a Chāran most often held the seat of the rājkavi, the post of the royal poet, as at the court of Bhuj, which gave them a higher social status in relation to other bards. Moreover, royal rituals were found to hold the key to an important regional religious practice: the veneration of human goddesses (Chāra $1 / 2$ Mātajjis). The consideration of the ritual royal order in Kacch revealed that bardic women played a ritual role (drinking blood) in the royal sacrifices for the goddess.

41 The modernisation theories of the 1960s and 1970s used to predict that caste would vanish under the forces of modernity. However, this belief has been firmly dislodged, caste now generally being acknowledged as an important contemporary category shaping diverse social realities in postcolonial India. There is, moreover, a considerable level of debate going on in the social sciences as to how the contemporary phenomenon of caste should be understood. Many of these debates are guided by the dichotomy between « religion " and the " secular ", in which caste is equated with religion. Change, then, may be understood in terms of democratic political processes which will ultimately lead to the " secularisation " of caste $^{25}$. A similar implicit dichotomy is found in the work of ethnohistorians arguing against the Dumontian paradigm of the separation of status and power and for the proliferation of regional systems of caste based upon royal power and institutions of kingship ${ }^{2} 6$. The ongoing controversy between Dumontians and ethnohistorians concerns the constitution of caste whether it is a religious hierarchy or a system of power and dominance ruled by the king. For understanding contemporary processes of caste, however, the notion of « substantialisation » in terms of a " transition from structure to substance " as suggested by Dumont still seems to provide a useful category for understanding the fusion of ritual and political dimensions in the lived reality of caste in contemporary times ${ }^{2} 7$. The frame of reference defining the status of Chāran in their own eyes remains locked into the former institution of kingship encompassed by the power of the goddess. Thus, the respect accorded to court poets in the past is still considered the foundation upon which the status of the Chāra $1 / 2$ caste rests in the present. But at the very moment when the outside context of kingship vanished, praise, advice and rebuke ceased to be addressed to the king and began to be focused on the entire caste instead. Castes in their turn may no longer be seen as integrated parts of social systems, as social configurations organised along the lines of hierarchy or patron-client relationships embedded in the institution of kingship, instead manifesting themselves as social universes in their own right. This process is, moreover, strengthened by the politics of affirmative action and the creation of the administrative category of the " Other Backward Castes » (OCB) which includes the Chāra $1 / 2$.

Considering also the critique raised by postcolonial studies namely that many of the categories that anthropologists work with heuristically owe their explanatory force to the fact that they are colonial constructions ${ }^{28}$, an investigation of indigenous constructions of caste as those articulated by poets may be instructive. These representations do not only speak of the power of the king as instrumental in creating a social order of caste 
identities (the sacrificial order of kingship) but also of the power of the goddess. The celebrations of the birthday of Sonal Mātàjī evoke realities of caste in terms of a community of sentiments through strategies of ritualisation. In this way, moreover, a distinction within the caste between the elite and commoners is created, guaranteeing at the same time the power of the caste over its members. In this case at least, practices of praise are the means whereby contemporary constructions of identity of a Chāra $1 / 2$ caste are sustained.

\section{NOTES}

*. I am grateful to Angelika Malinar for her interest in the subject and a host of valuable suggestions. Bob Parkin I would like to thank for his careful reading of the manuscript. 1. Pierre BOURDIEU, Entwurf einer Theorie der Praxis, Frankfurt/M., Suhrkamp, 1979; The Field of Cultural Production, Cambridge, Polity Press, 1993

2. Arjun Appadurai, « Topographies of the Self: Praise and Emotion in India », in Catherine LUTZ and Lila Abu-Lughod, Language and the Politics of Emotion, Cambridge,Cambridge University Press, 1990, p. 92 -112.

3. First of all, praise in the form of stotra is a ritual offering dedicated to a deity; in the form of dānastuti, praise is rendered as a symbolic tribute offered to a patron. Secondly, praise constitutes an art that is embedded in formal aesthetic frameworks.

4. S. Settar and M.M. Kalaburgi, « The Hero Cult: A Study of Kannada Literature from 9th to 13th Century ", in S. Settar and Günther Sontheimer, eds., Memorial Stones. A Study of their Origin Significance and Variety, Dharwad-Heidelberg, Institute of Indian Art History Karnatak University, 1982, p. 17-36.

5. Hiralal Maheshvari, History of Rajasthani Literature, Delhi, Sahitya Akademi, 1980, p. 10-12.

6. Friedhelm Hardy, The Religious Culture of India: Power, Love and Wisdom, Cambridge, Cambridge University Press, 1995

p. 112.

7. Helene BASU, Von Barden und ihren Königen: Studien zur Göttin und zum Gedächtnis in Kacch (Indien), Berlin, Peter Lang Verlag, 2004.

8. See also Satish SABERWAL, « On the Diversity of Ruling Traditions », in Sudipta KAVIRAJ, ed. Polotics in India, Delhi, Oxford University Press, 1997.

9. Harald Tambs-Lyche, Power, Profit and Poetry: Traditional Society in Kathiawar, Western India, Delhi, Monohar, 1997, p. 224ff.

1. ${ }^{0}$ Francoise Mallison, « Braj, Gujarati and Bardic Poetry Patronised by the Rulers of Kutch: The Bhuj-Braj-Bhasha Pathshala (1749-1949) », Paper presented at the Symposium Journées Gujarat, Paris 2003.

1. ${ }^{1}$ See for Saurashtra Harald TAMBS-LYCHE, « Le roi et les enfants de la déesse. Quelques contes du Saurashtra », Cahiers de Littérature Orale, 1991, 20, p. 61.85. Helene BASU, op. cit. 2004, p. 85-92. 
1. ${ }^{2}$ Clifford Geertz, Negara: The Theatre State in Nineteenth Century Bali, Princeton, Princeton University Press, 1980. Nicholas B. Dirks, The Hollow Crown: Ethnohistory of an Indian Kingdom, Cambridge, Cambridge Unviersity Press, 1987.

1. ${ }^{3}$ Trāgu, i.e. cutting the body with a dagger, causing it to bleed, in extreme cases until death, was a means of pressure that a Chāran could resort to in order to enforce an agreement between opponents. Trāgu as a form of self-sacrifice was performed either against one "s own body or against the body of a close family member, most often an old woman or a young girl. These acts could be used as a means of protest (Denis Vidal, Violence and Truth: A Rajasthani Kingdom Confronts Colonial Authority, Delhi, Oxford University Press, 1997, p. 15). In addition, in Kacch trāgu was part of a special type of service that Chāran people provided and by which they stood security for a contract. No contract between kings after a war, or between patrons and clients agreeing the terms whereby services be rendered, nor any other contract was considered valid without a Chāran guaranteeing on his own and/or the life of his family that the terms agreed upon would be fulfilled. They provided the same service for merchants and traders on their long treks through the desert up north, when they accompanied caravans for their protection against plundering bandits. Owing to the popular conviction that the spilling of the blood of a Chāran is an even greater sin than killing a Brahman, men and women of the caste who threatened to wound or kill themselves provided an effective protection against attackers of all sorts. Colonial discourse, however, defined acts of trāgu as murder and in the British-controlled parts of Gujarat the practice was soon declared a criminal act, for which individual Chāran were sent to prison. For a detailed analyses of the impact of colonialism upon this aspect of Chāran identity.

1. ${ }^{4}$ Cf. Appendix 2.

1. ${ }^{5}$ See for medieval deified Chāran women, Harald Tambs-Lyche, [20]Shakti. « The sacred powers of Chāran women in Gujarat », Paper presented for the $12^{\text {th }}$ European Conference of South Asian Studies, Berlin 1992. For symbolic transformations of the representation of Chāran Mātājis of the past, Helene BASU, op. cit.,, 2004, p. 195-198.

$1 .^{6}$ Chāran human goddesses represent one variant of diverse traditions of female asceticism in India, for other models cf. Catherine Clémentin-Ojha, « Feminine Ascetism in Hinduism: Its tradition and present condition ", Man in India, 1981, 61, 3, p. 254-285. Lynn Teskey Denton, Varieties of Female Ascetism, in Julia Leslie, ed., Roles and Rituals for Women, Delhi, Motilal Banarsidass, 1992, p. 211-231.

1. ${ }^{7}$ Helene Basu, « Local Concepts of Women Ascetics: Living Goddesses of the Chāran ", Journal of the Social Sciences (Delhi), 2000, Vol. 4, 4, p. 313-321.

1. ${ }^{8}$ While elsewhere in Gujarat ascetic women wear a saffron-coloured sari, Chāran Mātājīs communicate their consecrated Chāran femaleness by using the proper items (skirt, blouse, headscarf) of Chāran dress, though not in the original colours of red and black. As Gadhvi men and women themselves recognise, the wearing of saffron-coloured clothes by Chāran Mātājīs $s$ is a recent invention, perhaps stimulated partly by the marked increase in prestige offered publicly to Hindu ascetics (sādhu, samnyāsin ) and the colour signifying their status.

1. ${ }^{9}$ The public recognition of the decisions of the caste council and the open display of conformity do not mean, however, that all people actually agree or in their personal behaviour actually conform to everything proposed by the Chāran Samāj. «Small people » may secretly mock and ridicule the presumptuous air of «big people », but one would not 
openly defy those in authority nor question their norms, so long as one lives embedded in face-to-face-relationships with other Gadhvi.

2. ${ }^{0}$ It has to be noted with sorrow that by the time of writing this article Nārāyan Srāmī has passed away.

$2 .{ }^{1}$ For an example of a poem in the duho style composed by a local poet, see Appendix 1 .

$2 .{ }^{2}$ For an example of such a vocal performance, see Appendix 2.

$2 .{ }^{3}$ Thus, in several villages cells of the RSS have established saākhā-training camps. In one village, the organisation is run by a striving young poet and teacher who has opened a RSS village-school. Elsewhere in Kacch, Chāran young men run local organisations of the Shiv Sena. An analysis of the ideological transformations re-formulating local conceptions of the goddess in terms of a nationalist paradigm would require a separate study. I have dealt with this issue in more detail in another article, cf. Helene Basu, « Göttin in Indien - Indien als Göttin? » Historische Anthropologie, 12-1, 2004, p. 123-133. 2. ${ }^{4}$ A.M. Shah and R.G. Shroff, " The Vahivanca Barots of Gujarat: A Caste of Genealogers and Mythographers ", in Milton Singer, ed., Traditional India Structure and Change, Philadelphia, American Folklore Society, 1959, p. 40-70.

2. ${ }^{5}$ Rajni Kothari, « Caste and Modern Politics », in Sudipta Kaviraj, ed., Politics in India. Delhi, Oxford University Press, 1997, p. 57-70, p. 69.

$2 .{ }^{6}$ Cf. Gloria Goodwin Raheja, « India: Caste Kingship and Dominance Reconsidered ", Annual Review of Anthropology, 1988, 17, p. 497-522. Declan Quigley, The Interpretation of Caste, Oxford, Clarendon Press, 1993.

2. ${ }^{7}$ Louis Dumont, Homo hierarchicus: The Caste System and its Implications. Chicago, The Univesity of Chicago Press, 1980, p. 226.

2. ${ }^{8}$ Nicholas Dirks, Castes of Mind: Colonialism and the Making of Modern India, Princeton, Princeton University Press, 2001.

\section{RÉSUMÉS}

Il s'agit dans cet article d'une analyse de rites de louanges célébrés par les bardes traditionnels des anciens rois Rajput au Kacch. Après l'abolition de la royauté Rajput de nouveaux rituels commémoratifs en rapport avec les pratiques de louanges sont apparues, dans lesquels on retrouve la réalité vécue de la caste canaçontemporaine. Alors que la louange était une pratique importante consacrant le rôle du roi Rajput, dans le Kacch post-indépendant, un déplacement significatif en ce qui concerne l'objet des louanges s'est produit. Ce n'est plus sur le roi que la louange se concentre mais sur la déesse incarnée par des femmes cană La description d'un rituel célébré pour une déesse Canāvivante, vénérée également comme réformatrice sociale, dessine des processus qui redéfinissent la caste dans le cadre de l'Inde postcoloniale.

This paper presents an analysis of performances of praise practiced by traditional bards of former Rajput kings in Kacch. After the abolition of Rajput kingship, new commemorative rituals have come into being that depend on practices of praise whereby the lived reality of the contemporary Canaxaste is produced. While praise was an important practice legitimating the role of the Rajput king, in post-independent Kacch a noticeable shift has taken place in regard to the 
object of praise. It is no longer the king upon whom praise is centred but the goddess embodied in Canawomen. The description of a ritual performed for a living Goddess of the canawho is venerated at the same time as a social reformer delineates processes of re-defining cast in postcolonial Indian settings.

Este artículo ofrece un análisis de las representaciones de alabanza o elogio practicadas por los bardos tradicionales de los antíguos reyes Rajput en Kacch. Tras la abolición de la monarquía Rajput han surjido nuevos rituales conmemorativos, que dependen de prácticas de elogio, las cuales a su vez producen la realidad vivida por la casta Canācontemporánea. Si bien el elogio fué una importante práctica que legitimaba el rol del rey Rajput, en el Kacch post-independiente ha tenido lugar un notorio cambio con repecto al objeto de alabanza, que ya no se centra en el rey, sino en la deidad personificada por la mujer Canā La descripción de un ritual representado para una diosa viviente de los Cană que al mismo tiempo es venerada como reformadora social, delinea procesos de redefinición de castas en las circunstancias dadas en la India postcolonial.

\section{AUTEUR}

\section{HELENE BASU}

Freie Universitaet Berlin 